\title{
Aportaciones del sistema Unilock 2.0 a la osteosíntesis mandibular
}

\section{Contributions of the $\mathbf{2 . 0}$ unilock system to mandibular osteosynthesis}

\author{
S. Martínez-Villalobos Castillo', M.A. Sicilia Gutiérrez², L.M. Capitán Cañadas², \\ A. Labrot Moleon², D. Sánchez López', E. Valencia Laseca³
}

Resumen: El sistema Unilock 2.0 constituye la última generación de placas que incorporan el "principio de bloqueo" en su concepción y diseño. Desarrolladas a partir del sistema Unilock 2.4, aportan mayor sencillez y comodidad en su manejo incorporando muchas de sus prestaciones biomecánicas y abarcando además todas las indicaciones de las miniplacas convencionales. En este artículo revisamos sus características técnicas, sus indicaciones clínicas así como nuestra experiencia en su empleo para diferentes situaciones precisadas de osteosíntesis mandibular.

Palabras clave: Osteosíntesis mandibular; Placas de bloqueo; Sistema Unilock; Placas de reconstrucción mandibular; Miniplacas.

\section{Introducción}

\section{Principios biomecánicos}

El principio de bloqueo, también denominado del "fijador internoexterno", es un principio biomecánico bien conocido y ampliamente aceptado por sus indudables beneficios sobre la viabilidad de determinadas osteosíntesis, fundamentalmente aquellas en las que se necesita una fijación rígida que garantice una estabilidad adecuada tras la reparación de graves fracturas (múltiples, conminutas, etc.) o defectos mandibulares (traumáticos u oncológicos). En virtud de este principio, la necesaria estabilidad del sistema que constituyen el implan-

\footnotetext{
1 Médico Adjunto.

2 Médico Residente.

3 Jefe de Servicio.

Servicio de Cirugía Oral y Maxilofacial.

Hospital Universitario "Virgen de las Nieves". Granada, España.

Correspondencia:

Sergio Martínez-Villalobos Castillo

Servicio de Cirugía Oral y Maxilofacial. HRT

Hospital Universitario "Virgen de las Nieves"

Avda. Fuerzas Armadas 2. Granada 18014

smvillalobos@terra.es
}

Abstract: The 2.0 Unilock System is the last generation of plates that incorporate the "lock principle" in their conception and design. Developed from 2.4 Unilock System, they contribute major simplicity and comfort in their managing incorporating many of its biomechanics excellences and including all the indications of the conventional miniplates. In this article we review their technical characteristics, their clinical indications as well as our experience in their use for different situations needed of mandibular osteosynthesis.

Key words: Mandibular osteosynthesis; Locking plates; Unilock system; Mandibular reconstruction plates; Miniplates.

\section{Introduction}

Biomechanical principles

The locking principle, also called the "internal-external fixator" is a biomechanical principle that is well-known and widely accepted because of the undoubted advantages that it has regarding the viability of certain osteosyntheses, fundamentally those requiring rigid fixation to guarantee adequate stability following the repair of serious fractures (multiple, comminuted...) or mandibular defects (traumatic or oncologic). By virtue of this principle, the required stability of the system, which consists of the implant and the bone, does not depend on intimate contact between them, that is to say on the plate adapting perfectly to the morphology bone that has been repaired. Technically this is possible because the fixations screws are anchored to the holes of the plate in such a way that the loading forces are transmitted directly from the bone to the screws and from the screw heads down the whole length of the plate, without the need for the latter to be completely fixed to the bone (Fig. 1a). Without prejudicing the efficiency of biomechanics, this is in principle a "relief" given the complexity of three-dimensional molding of conventional plates (especially if these are very long 
te y el hueso no depende del íntimo contacto entre ellos, es decir, de una perfecta adaptación de la placa a la morfología del hueso reparado. Técnicamente esto es posible por el anclaje de los tornillos de fijación en los agujeros de la placa, de forma que las fuerzas de carga se trasmiten directamente desde el hueso a los tornillos y desde las cabezas de éstos a todo lo largo de la placa, sin necesidad de que ésta esté adosada completamente al hueso (Fig. 1). Esto, en principio, supone un "alivio" en la complejidad del moldeado tridimensional de las placas convencionales (sobre todo si estas son muy largas y de elevado perfil) sin menoscabo de la eficacia biomecánica. Evidentemente esto no quiere decir que el implante pueda ser fijado de cualquier forma, ya que podrían afectarse otros aspectos como la simetría facial o incrementarse la siempre indeseable palpabilidad.

Con las técnicas convencionales la inserción de los tornillos comprime la placa sobre el hueso, situación necesaria para conseguir la reducción anatómica de los fragmentos y una adecuada estabilidad primaria pero que puede comprometer la vascularización de la cortical externa (Fig. 1). De otra parte, si el implante no esta perfectamente moldeado a la anatomía del hueso subyacente se puede producir una pérdida primaria de la reducción, por tracción del tornillo sobre el hueso para adosarle a la placa. La pérdida secun-
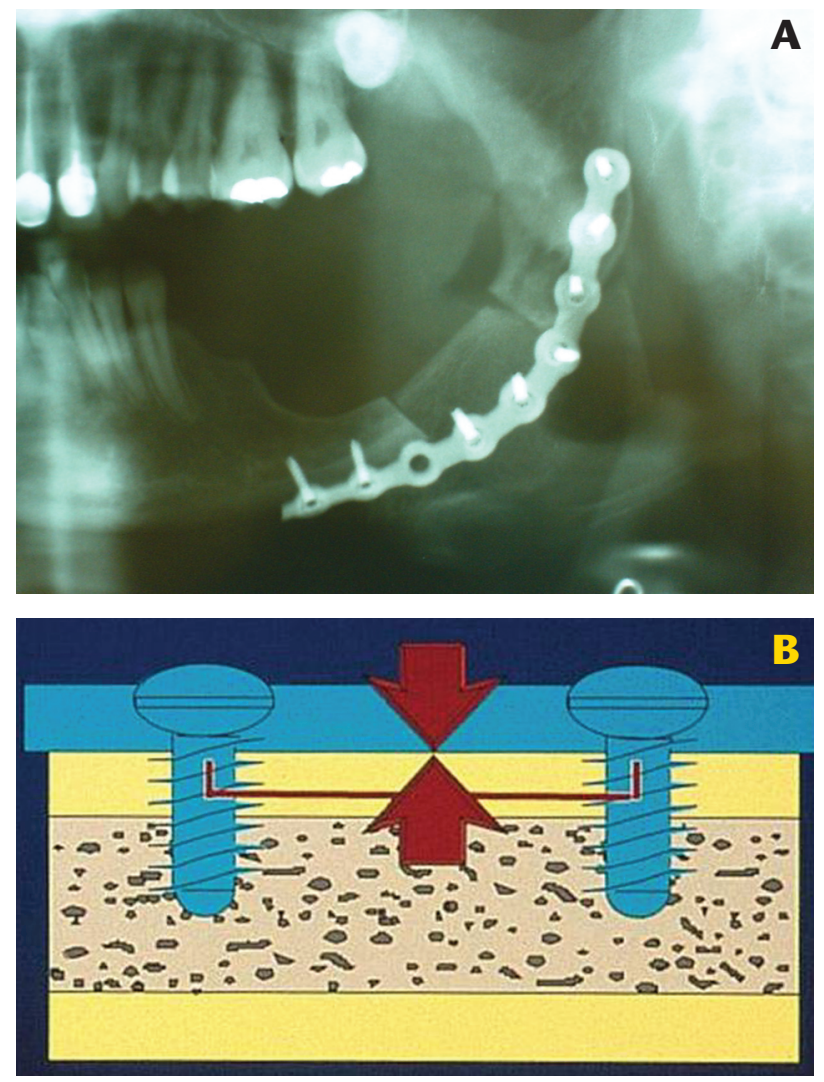

Figura 1. A) Esquema del principio de bloqueo. La carga mecánica se soporta con independencia del contacto con el hueso, lo que favorece la vascularización de la cortical y por tanto la consolidación. B) Esquema de un sistema convencional. La estabilidad de la osteosíntesis depende del íntimo contacto entre la placa y el hueso.

Figure 1. A) Diagram of locking principle. The mechanical load is supported independently of bone contact, which favors vascular supply to the cortex and therefore consolidation. B) Diagram of a conventional system. The stability of the osteosynthesis depends on intimate plate/bone contact.

A and with a high profile). Evidently this does not mean to say that the implant can be fixed in any way, as other aspects may be affected such as facial symmetry, or palpability -always undesiredcould increase.

With conventional techniques, the insertion of screws compresses the plate onto the bone, which is a necessary condition for reducing the fragments anatomically and for obtaining adequate primary stability, but this can compromise the blood supply to the external cortex (Fig. $1 b)$. On the other hand, if the implant is not perfectly molded to the anatomy of the subjacent bone, primary loss of reduction occurs because of the traction of the screw on the bone needed for securing it to the plate. Secondary loss of reduction is also more frequent in conventional systems, as the resulting loading forces and micro-movements may lead to loosening of the screws and instability. In both cases the consequence tends to be malocclusion. Finally, with locking systems over tightening the daria de la reducción también es más frecuente en los sistemas convencionales, ya que las fuerzas de carga y los micro-movimientos que éstas condicionan pueden provocar aflojamiento de los tornillos e inestabilidad. En ambos casos la consecuencia suele ser una maloclusión. Finalmente, con los sistemas de bloqueo se previene el paso de rosca de los tornillos durante su inserción, ya que antes que esto pueda suceder quedan anclados en el agujero de la placa. En consecuencia, el aflojamiento y la secundaria inestabilidad (con maloclusión y/o infección) se previenen, por ejemplo cuando un tornillo se inserta en el foco de fractura.

En resumen, los sistemas de bloqueo aportan mayor estabilidad, menor compromiso vascular óseo y minimizan los posibles errores de la técnica de osteosíntesis estándar, aportando unos índices de complicaciones y fracasos inferiores a los sistemas convencionales. ${ }^{1-7}$ Además, la fijación intermaxilar postoperatoria puede obviarse o verse reducida al mínimo en ausencia de fractura condílea y/o del tercio medio facial asociada.

Los sistemas de anclaje "placa-cabeza de tornillo" han evolucionado a su vez simplificándose, desde los originales del sistema screws is avoided during insertion, as before this can take place they are anchored into the holes of the plate. Consequently, loosening and secondary instability (with malocclusion and/or infection) is prevented, as occurs for example when a screw is inserted into a fracture site.

In short, locking systems provide greater stability while vascular supply to the bone is less impaired. Possible errors in standard osteosynthesis techniques are minimized and complication and failure rates, compared with conventional systems, are lowered..$^{1-7}$ In addition, postoperative intermaxillary fixation can be avoided, or reduced to the minimum, if there is no condyle and/or associated mid-face fracture.

"Plate-screw head" anchoring systems have evolved becoming simpler, from the original 4.0 Thorp system (in disuse) to the current 2.4 and 2.0 Unilock system (Fig. 2).

\section{Technical characteristics}

There are three types of 2.0 Unilock plates that perform the functions of many other conventional systems. The Mini, 


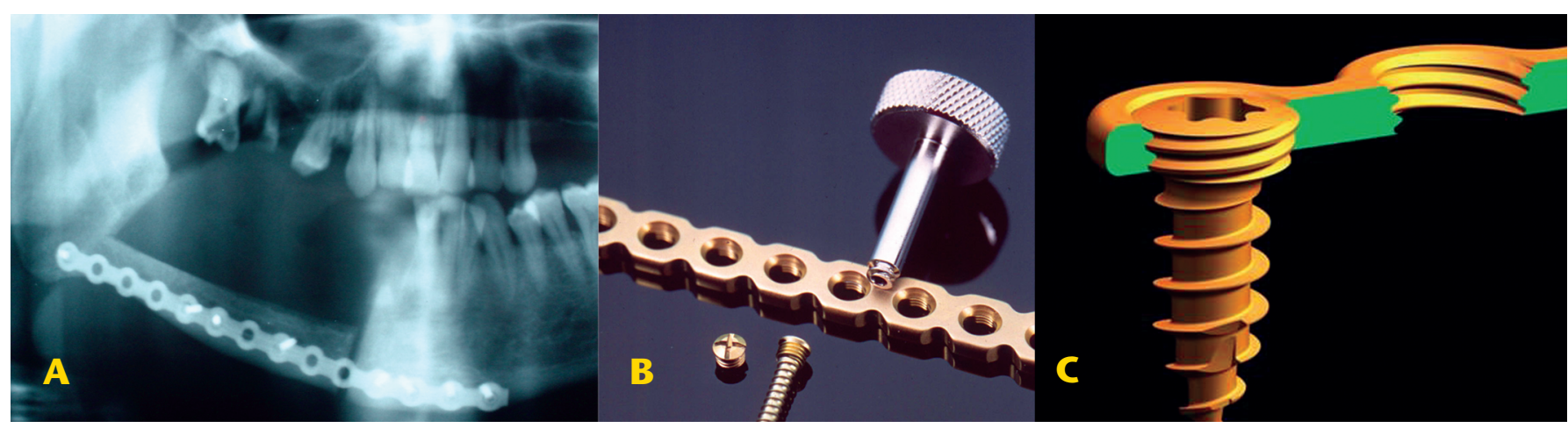

Figura 2. Evolución de los sistemas de bloqueo. A) Thorp 4.0: el pequeño tornillo que se enrosca en la cabeza del tornillo de fijación expande la cabeza de este contra el agujero de la placa, produciendo así el efecto de bloqueo. B) Unilock 2.4: el agujero de la placa y la cabeza del tornillo poseen una rosca mediante la que quedan engarzados. Durante el moldeado, los agujeros deben ser protegidos con unos pequeños tornillos sin vástago para evitar la deformidad e inutilización de la rosca. El brocado precisa además de una guía de broca para que el agujero sea perfectamente céntrico. C) Unilock 2.0: el diseño del tornillo hace innecesarias las precauciones citadas para el 2.4

Figure 2. Evolution of the locking systems. A) 4.0 Thorp: the small screw that goes into the head of the fixation screw expands the head of the latter against the plate hole, thus producing the locking effect. B) 2.4 Unilock: the plate hole and the head of the screw have threads so that they lock into each other. On molding, the holes should be protected with small short screws so that they are not deformed and the thread+ rendered useless. A drill guide is also needed so that the hole is correctly centered. C) 2.0 Unilock: the design of the screw makes the warnings given for the 2.4 [system] unnecessary.

Thorp 4.0 (en desuso) a los actuales del sistema Unilock 2.4 y 2.0 (Fig. 2).

\section{Características técnicas}

Existen tres tipos de placas Unilock 2.0 que vienen a cubrir la función de otros tantos sistemas convencionales. Las pequeñas (Mini), con un perfil de $1 \mathrm{~mm}$ hacen la función de las miniplacas 2.0 estándar. Las medianas (Médium), con un perfil de $1.3 \mathrm{~mm}$ hacen la función de las 2.0 DCP y las grandes (Large) de $1.5 \mathrm{~mm}$ de perfil, que son el equivalente a las 2.4 univer-

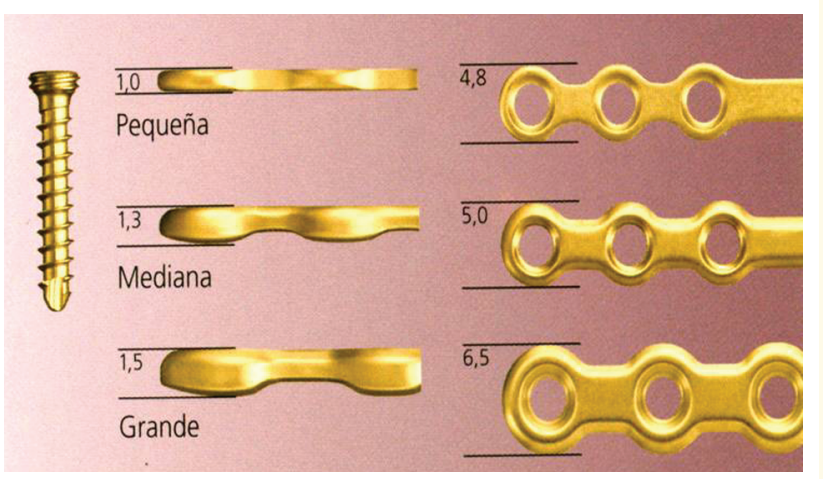

Figura 3. La familia de placas Unilock 2.0. Figure 3. The family of 2.0 Unilock plates. with a $1 \mathrm{~mm}$ profile performs the same functions as the standard 2.0 miniplate. The Medium with a $1.3 \mathrm{~mm}$ profile performs the same functions as the 2.0 DCP, and the Large with a $1.5 \mathrm{~mm}$ profile is the equivalent of the universal 2.4 fracture [plates]. Unlike the 2.4 Unilock plate, protective screws are not needed for folding and contouring. The three plates are fixed with the same screws with a diameter of $2 \mathrm{~mm}$, lock 2.4 no necesitan de tornillos protectores para su doblaje y moldeado. Las tres placas se fijan con los mismos tornillos de $2 \mathrm{~mm}$ de diámetro disponibles entre 5 y $18 \mathrm{~mm}$ de longitud, lo que permite una fijación bicortical en las osteosíntesis basales. Son tornillos de titanio-aluminio-niobio, autoroscantes, con una ranura autoretentiva para el destornillador denominada Stardrive. Se dispone de tornillos de bloqueo (con rosca en su cabeza) y tornillos normales que pueden, por tanto, insertarse de forma oblícua para atravesar por ejemplo el foco de fractura de una cortical a otra. Finalmente, hay que destacar que tampoco necesitan de guía de brocado, ya que el diseño del tornillo hace que se autocentre (Fig. 3).

\section{Material y método}

En los últimos 24 meses se ha desarrollado en nuestro Servicio un estudio observacional prospectivo de una cohorte constituida por 36 pacientes que han sido tratados con placas del sistema Unilock 2.0. La gran mayoría han sido fracturas mandibula- available in lengths ranging between 5 and $18 \mathrm{~mm}$, allowing bicortical fixation in basal osteosyntheses. These are titanium-aluminum-niobium screws, which are self-tapping, has locking screws (with a threaded head) and normal screws, which can be inserted obliquely so that the fracture site can therefore be penetrated from cortex to cortex. Finally, the fact that a drill guide is not needed should be emphasized as the design of the screw means that it self-centers (Fig. 3).

\section{Material and method}

Over the last 24 months a prospective observational study was carried out in our Service of a cohort consisting of 36 patients treated with the 2.0 Unilock plate system. The large fering situations requiring mandibular osteosynthesis. Fortyeight fixations were carried out in total. The patients were evalwith a self-retentive recess for the Stardrive screwdriver. It majority had fractures of the mandible and the rest had dif- 
Tabla 1. Características de las osteosíntesis practicadas.

\begin{tabular}{|c|c|c|c|c|}
\hline Osteosíntesis & № Casos & 2.0 Locking Plate & BEIM. Postop. & Complicaciones \\
\hline \multicolumn{5}{|l|}{ Fractura mandibular } \\
\hline Simples (no desplazadas) & 15 & Mini & 7 (Cond.+) & \\
\hline $\begin{array}{l}\text { Complejas } \\
\text { (múltiple y/o desplazadas) }\end{array}$ & 9 & Mini/Medium & 6 (5 Cond. + ) & 1 Maloclusión \\
\hline Conminutas & 2 & $\begin{array}{l}\text { Mini/Medium/ } \\
\text { Large }\end{array}$ & 1 (Cond.+) & $\begin{array}{c}1 \text { Infección } \\
1 \text { Retirada placa }\end{array}$ \\
\hline \multicolumn{5}{|l|}{ Osteotomías } \\
\hline Trotter & 3 & Medium & No & \\
\hline Mandibulotomía lateral & 1 & Large & No & \\
\hline \multicolumn{5}{|l|}{ Otras } \\
\hline Peroné microvascular & 4 & Large & No & \\
\hline IONV & 1 & Large & $\mathrm{Si}$ & \\
\hline F. Panfacial & 1 & Mini/Medium & $\mathrm{Si}$ & \\
\hline Total & 36 & 48 & 16 & 3 \\
\hline
\end{tabular}

Table 1. Characteristics of the osteosynthesis performed.

\begin{tabular}{|c|c|c|c|c|}
\hline Osteosynthesis & № Cases & 2.0 Locking Plate & Postop. IMET. & Complications \\
\hline \multicolumn{5}{|l|}{ Mand. fracture } \\
\hline Simple (not displaced) & 15 & Mini & 7 (Cond. + ) & \\
\hline $\begin{array}{l}\text { Complex } \\
\text { (multiple and/or displaced) }\end{array}$ & 9 & Mini/Medium & 6 (5 Cond. + ) & 1 Malocclusion \\
\hline Comminuted & 2 & $\begin{array}{l}\text { Mini/Medium/ } \\
\text { Large }\end{array}$ & 1 (Cond.+) & $\begin{array}{c}1 \text { Infection } \\
1 \text { Plate removal }\end{array}$ \\
\hline \multicolumn{5}{|l|}{ Osteometies } \\
\hline $\begin{array}{l}\text { Trotter } \\
\text { Lateral }\end{array}$ & 3 & Medium & No & \\
\hline Mandibulotomy & 1 & Large & No & \\
\hline \multicolumn{5}{|l|}{ Others } \\
\hline Fibula & 4 & Large & No & \\
\hline NVBG & 1 & Large & Yes & \\
\hline Panfacial F. & 1 & Mini/Medium & Yes & \\
\hline Total & 36 & 48 & 16 & 3 \\
\hline
\end{tabular}

res y el resto diferentes situaciones precisadas de osteosíntesis mandibular. En total 48 fijaciones han sido realizadas. Los pacientes han sido evaluados intraoperatoriamente y durante el seguimiento postoperatorio para determinar los beneficios del sistema: características de los defectos mandibulares, manejabilidad y complicaciones (Tabla 1).

\section{Resultados}

Casi la mitad de los pacientes presentaban fracturas simples mandibulares, entendiendo como tales aquellas no desplazadas aunque fuesen dobles. El resto fueron fracturas complejas (múltiples y/o desplazadas) y situaciones específicas que serán posteriormente argumentadas. En todos los pacientes, salvo uno edéntulo, la osteosíntesis se realizó bajo control oclusal con fijación intermaxilar, bien con tornillos IMF o con ferulización bimaxilar dependiendo de las carac- uated intraoperatively and postoperatively in order to determine the benefits of the system: characteristics of the mandibular defects, ease of use and complications (Table 1).

\section{Results}

Nearly half the patients presented simple mandibular fractures and non-displaced fractures, even if they were double, were considered as such. The rest were complex fractures (multiple and/or displaced) with specific situations that will be discussed later. In all patients, except for one edentate patient, osteosynthesis was carried out with occlusal control and intermaxillary fixation, either with IMF screws or with bimaxillary splints, depending on the dental characteristics and on the presence or not of an associated condylar fracture. The approach chosen depended on the local- 
terísticas de la dentición y de la presencia o no de fractura condílea asociada. El abordaje seleccionado dependió de la localización de la fractura y del grado de desplazamiento, aunque resultó electivo el abordaje intraoral y transbucal cuando fue posible. La elección de la placa dependió de las necesidades biomecánicas de cada caso, siendo éstas más gruesas y largas a mayor grado de desplazamiento, en jóvenes totalmente dentados y en los casos en que se presumía una falta de colaboración sociosanitaria postoperatoria adecuada. En los casos de "osteosíntesis reconstructiva" siempre se utilizo una placa "grande" (1.5 mm de perfil). En todos los casos la reducción anatómica de los fragmentos y la estabilidad primaria conseguidas fueron consideradas como muy buenas o excelentes, y el chequeo oclusal satisfactorio (Fig. 4).

Durante el postoperatorio se mantuvo bloqueo elástico intermaxilar solo en los pacientes afectos de fractura condílea asociada,

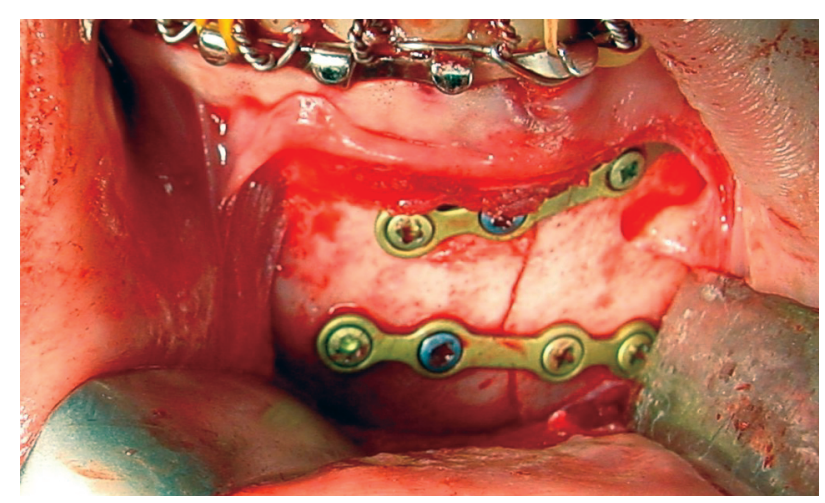

Figura 4. Fijación de fractura parasinfisaria con dos placas mini (1 $\mathrm{mm}$ ) Excelente reducción y estabilidad primaria. En ausencia de fractura condílea no es necesario el bloqueo intermaxilar postoperatorio.

Figure 4. Fixation of a parasymphyseal fracture with two mini plates $(1 \mathrm{~mm})$. Excellent reduction and primary stability. If there is no condylar fracture, postoperative intermaxillary fixation is not necessary.

ization of the fracture and the degree of displacement, although the approach of choice was intraoral and transbuccal when possible. Plate election depended on the biomechanical needs of each case, these being wider and longer the greater the degree of displacement, being used for young people with completed dentition and in those cases in which a lack of adequate postoperative sociosanitary collaboration was assumed. In cases of "reconstructive osteosynthesis" a large plate was always used (1.5 $\mathrm{mm}$ profile). In all cases the anatomical reduction of the fragments and the primary stability achieved were considered very good or excellent, and the occlusal assessment satisfactory (Fig. 4).
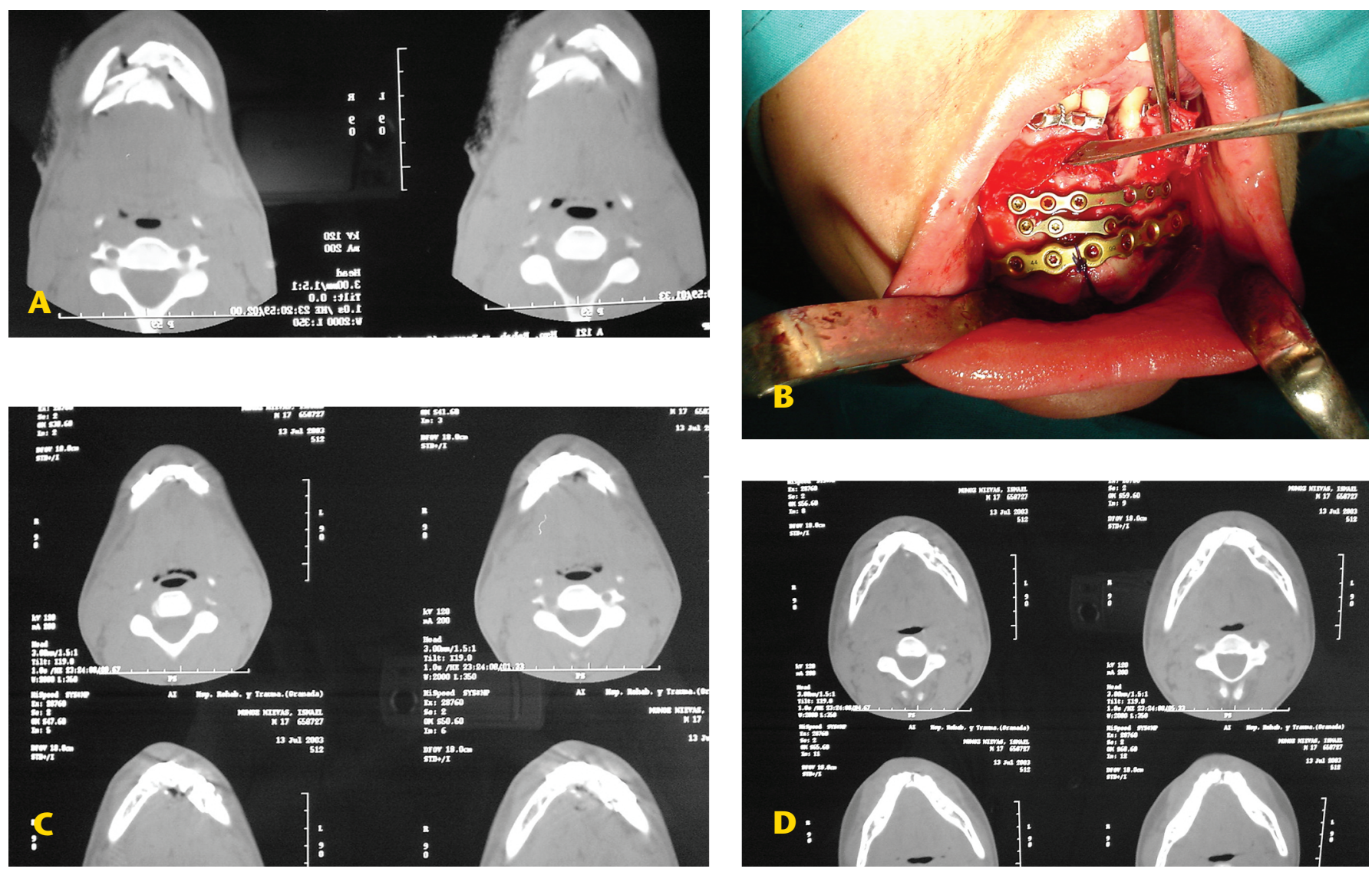

Figura 5. A) Fractura conminuta de sínfisis-cuerpo y cóndilo dcho. B) Fijación con placas mini y large basal con tornillos bicorticales. C,D) Controles postoperatorios.

Figure 5. A) Comminuted fracture of symphysis-body and right condyle. B) Fixation with mini-plates and large basal with bicortical screws. A) C,D) Postoperative controls. 
ninguna de las cuales fue subsidiaria de reducción abierta para osteosíntesis ( 7 de las 15 fracturas simples, 5 de las 9 fracturas complejas y en 1 de las 2 conminutas) en el caso de IONV (injerto óseo no vascularizado) y en la fractura panfacial, durante un período que osciló entre los 10 y los 21 días. El resto de los pacientes salieron de quirófano con la boca abierta. El único caso que presentó maloclusión, aun sin tener fractura de cóndilo, precisó de bloqueo intermaxilar durante 30 días. La paciente desestimó la reintervención y prefirió un tratamiento "conservador" que no solventó perfectamente la disoclusión, necesitando además un ajuste ortodóntico. Los controles radiológicos inmediatos practicados, incluyendo TC en algún caso de fractura compleja y en las conminutas, fueron considerados como satisfactorios, con un correcto alineamiento de los focos de fractura salvo en el caso de la referida maloclusión (Fig. 5). El seguimiento, exceptuando los casos oncológicos, ha oscilado entre las 8 semanas para las fracturas simples y los 12 meses para las más complejas, considerándose la consolidación definitiva en todos los casos (Fig. 6).

Respecto a las complicaciones, desestimadas las atribuidas a fracturas condíleas asociadas como limitación de apertura y latero-desviación, son las reflejadas en la Tabla 1: una maloclusión (ya comentada), una infección y una exposición de placa; en una de las fracturas abiertas y conminuta se presentó una infección tardía (más de 1.5 mes postop.) secundaria a una necrosis avascular de un fragmento de basal mandibular que había sido fijado con tornillos de tracción; se resolvió con su retirada, evidenciándose estabilidad del resto de las osteosíntesis y normoclusion (Fig. 7) La otra complicación presentada, a los dos meses de la intervención, fue la exposición extraoral de una placa mini a nivel sinfisario, en la otra fractura conminuta tratada con este sistema. Se trataba de un paciente casi edéntulo afecto de una fractura abierta por arma de fuego (bala) y se consideró la exposición como secundaria a la retracción cicatrizal de las partes blandas. Fue solucionada con retirada (a los 6 meses) del material de osteosíntesis expuesto sin necesidad de retirar el fragmento óseo que estaba consolidado (Fig. 8).

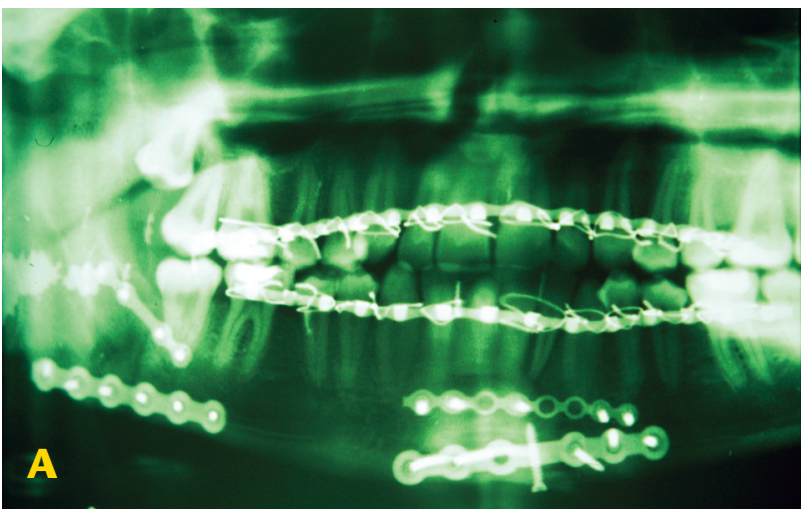

During the postoperative [period] intermaxillary elastic traction was maintained only in those patients with an associated condylar fracture, none of whom were given open reduction for osteosynthesis as a second choice (7 of the 15 simple fractures, 5 of the 9 complex fractures and 1 of the 2 comminuted fractures) in the NVBC (non-vascularized

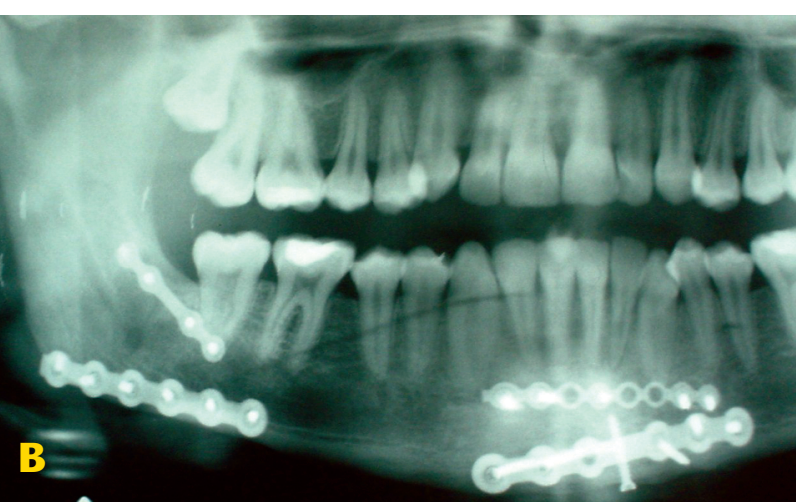

Figura 6. Fractura compleja: sinfisaria, angular y condílea. Postoperatorio inmediato (A) y a los 8 meses (B).

Figure 6. Complex fracture: symphyseal, angular and condylar. Immediate postoperative (A) and at 8 months (B).

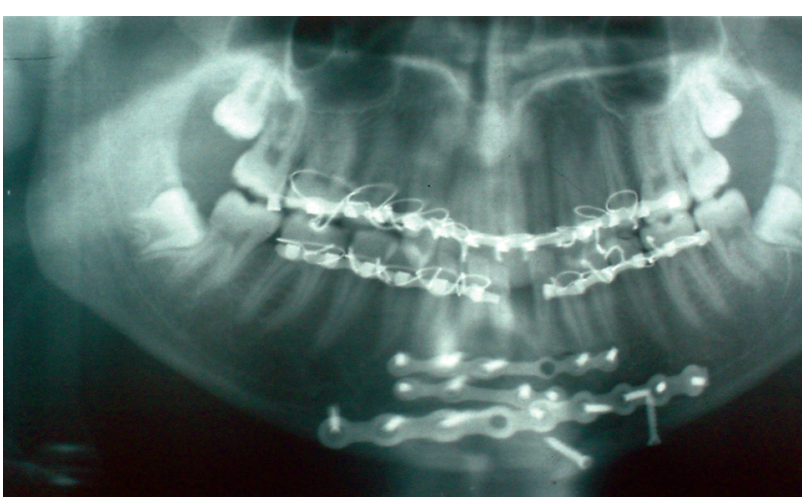

Figura 7. Necrosis avascular de fragmento basal. Corresponde al caso de la figura 5.

Figure 7. Avascular necrosis of basal fragment corresponding with the case in figure 5. bone graft) case and in the panfacial fracture, during a period which varied between 10 and 21 days. The rest of the patients left the operating room with mouths open. The only case presenting malocclusion, even though there was no condylar fracture, required intermaxillary fixation for 30 days. The patient did not wish to be reoperated, preferring "conservative" treatment that did not rectify the disocclusion perfectly, and she needed an additional orthodontic adjustment. The radiological controls, which were carried out immediately and which included a TC scan of the occasional complex fracture and comminuted case, were considered satisfactory as fracture sites were correctly aligned with the exception of the previously mentioned malocclusion (Fig. 5). The follow-up, with the exception of the oncologic cases, varied between 8 weeks for simple fractures and 12 months for more complex ones, and consolidation was considered definitive in all cases. (Fig. 6). With regard to complications, not including those attributed to associated condylar fractures such as aperture limitation and lateral deviation, these are reflected in table 1: one malocclusion (previously mentioned), one infection and one plate exposure. In one of the open comminuted fractures delayed infection developed (more than 1.5 months post-op.) secondary to an avascular necro- 

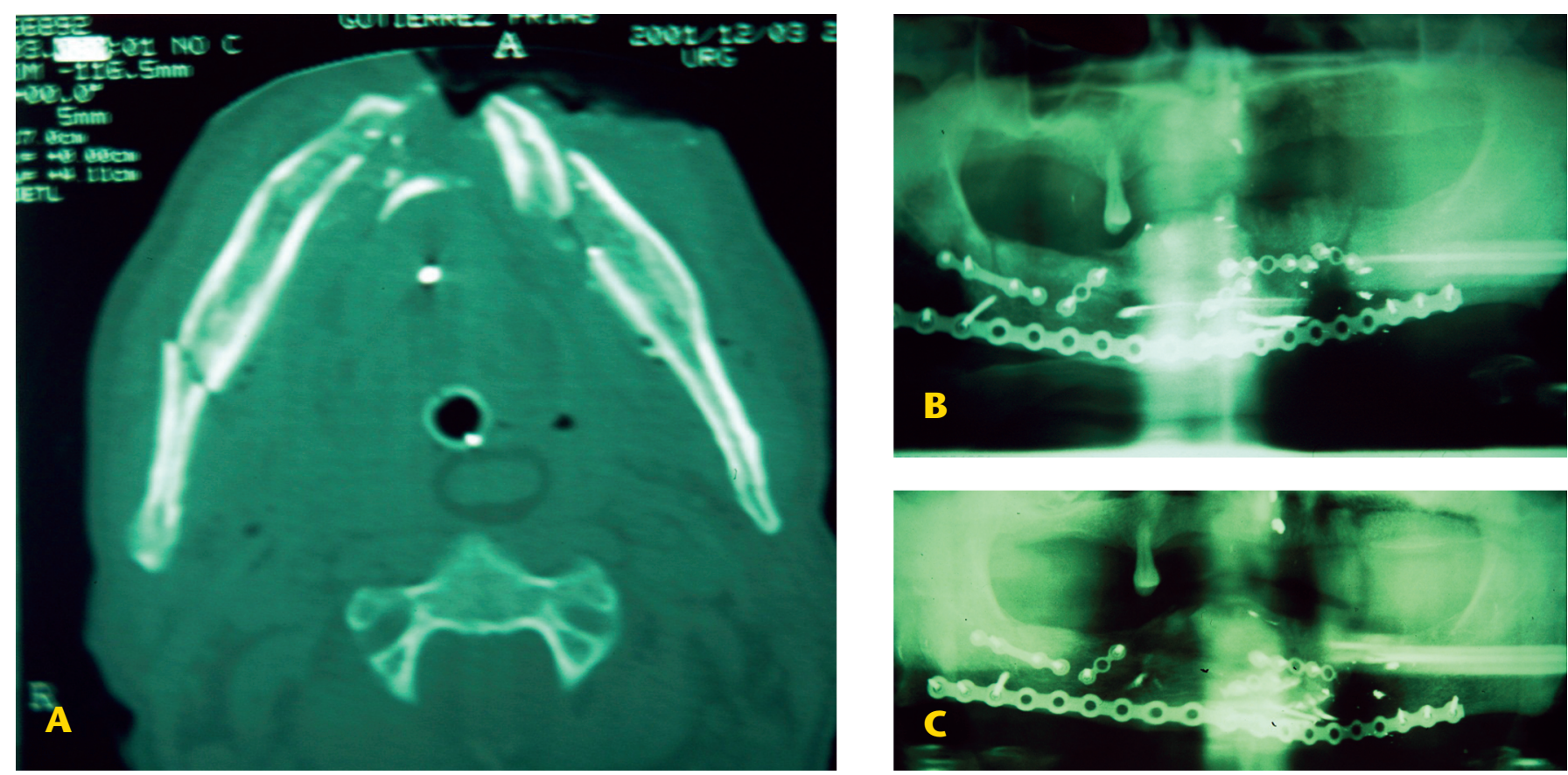

Figura 8. Fractura abierta y conminuta por HAF (A). Secuencia radiológica (B). Consolidación (C). Figure 8. Open and comminuted fracture with HAF (A). Radiologic study (B). Consolidation (C).

\section{Discusión}

El diseño del sistema Unilock 2.0 recoge dos inquietudes compartidas por la mayoría de los cirujanos orales y maxilofaciales implicados en el manejo de las técnicas de osteosíntesis: la utilización de implantes del más bajo perfil posible y la simplificación en su manipulación con las máximas garantías de estabilidad.8-14 Este "pragmatismo clínico", en necesaria y estrecha colaboración con la ingeniería y la industria, ha hecho posible su desarrollo (Synthes MaxiIlofacial, Paoli, PA-USA), aunque en el estudio multicéntrico previo a su comercialización (más de 200 casos) también han participado hospitales centroeuropeos. Se trataba pues de incorporar los beneficios de los sistemas de bloqueo (fundamentalmente Unilock 2.4) a implantes de más bajo perfil y, sobre todo, más fáciles de manejar intraoperatoriamente. Como ya hemos comentado, supone un importante alivio en el moldeado tridimensional de implantes largos, pero también resulta muy interesante en la manipulación de implantes pequeños para la osteosíntesis en lugares de difícil acceso como por ejemplo el cóndilo mandibular. La experiencia recogida en este estudio piloto define inicialmente las indicaciones y las limitaciones de este sistema (Tabla 2).

$\mathrm{Si}$ bien las indicaciones parecen estar bien asentadas (osteosíntesis load sharing), no podemos decir lo mismo de las contraindicaciones; en efecto, está bien establecido que la resistencia de estas placas no es adecuada para asumir situaciones de osteosíntesis load bearing (la única excepción sería la fijación de injertos óseos microvascularizados) como la osteosíntesis puente o la fijación de un IONV (Fig. 9) En el caso de las fracturas conminutas el implante de primera elección sería un sistema 2.4; nuestra serie recoge dos casos en los que la elección del sistema 2.0 no sis of a fragment from the mandibular base that had been fixed with traction screws; this was resolved by removing it, and stability of the remaining osteosyntheses was observed together with normocclusion (Fig. 7). The other complication that arose two months after intervention, was the intraoral exposure of a mini plate on a symphyseal level, in the other comminuted fracture treated with this system. This was a patient was nearly edentulous having an open fracture from a gun wound (bullet), and exposure was considered secondary to scar retraction of soft tissues. It was resolved by removing (at 6 months) the osteosynthesis material that had become exposed, and removal of the consolidated bone fragment was not needed (Fig. 8).

\section{Discussion}

The design of the 2.0 Unilock system encompasses two concerns for most maxillofacial surgeons concerned with the use of osteosynthesis techniques: the use of implants with the lowest possible profile and simplification of application with maximum guarantees of stability. 8-14 This "clinical pragmatism", while being necessary and tightening the collaboration with engineering and industry, has made its development possible (Synthes Maxillofacial, Paoli, PA-USA) even though in the multicentric study previous to its commercialization (more than 200 cases) central European hospitals have also participated. The aim is to combine the benefits of locking systems (fundamentally the 2.4 Unilock) with implants of a lower profile that can be more easily applied 
fue caprichosa: en el paciente fracturado por herida de bala su casi total edentulismo y sobre todo la situación de los tejidos blandos nos inclinó a tomar esta decisión buscando minimizar las posibilidades de exposición dado el menor perfil de las placas. En el segundo caso la presencia de una fractura de cóndilo y por tanto la necesidad de una fijación intermaxilar postoperatoria nos animó a emplear el sistema 2.0 con buenos resultados. En ambos casos la complicación puede ser considerada como independiente del sistema empleado, se presentó de forma diferida y en presencia de consolidación completa y normoclusión.

Respecto al caso de IONV, se trataba de una joven paciente, radiada, con una facies pequeña y una fina piel, además de unos bajos requerimientos biomecánicos (masticación/colaboración). El resultado fue muy satisfactorio, si bien es cierto que fue sometida a un bloqueo intermaxilar "preventivo" de tres semanas que quizás no hubiésemos efectuado de haber empleado un sistema 2.4 (Fig. 10).

En el caso de las osteotomías de abordaje, resultan una alternativa segura que en ocasiones además pueden reforzar las mandibulectomías marginales (Fig. 11) aunque en presencia de radioterapia habría que considerar en primer lugar un sistema 2.4. Finalmente, aunque se trata de un sistema diseñado específicamente para la osteosíntesis mandibular puede resultar muy útil en el caso de las fracturas panfaciales, ya que en el mismo set, con idénticas brocas y tornillos, podemos realizar las osteosíntesis del tercio medio y de la órbita (con placas mini) lo que simplifica enormemente la instrumentación (Fig. 12).

Evidentemente no se pueden sacar conclusiones de estos casos aislados, pero se pretende destacar que la frontera no está bien delimitada. Por ejemplo, no hay
Tabla 2. Comparativa de las placas Unilock 2.0 y sistemas convencionales según la dicación

$\begin{array}{lcc}\text { Indicaciones } & \text { Sistema convencional } & \mathbf{2 . 0} \text { Locking plates } \\ \begin{array}{l}\text { Fracturas simples } \\ \text { Ortognática }\end{array} & \text { Miniplacas } 2.0 & \mathrm{Si} \\ \begin{array}{l}\text { Fracturas múltiples } \\ \text { y complejas }\end{array} & \text { Universal de fract. } 2.4 & \mathrm{Si} \\ \text { Fracturas conminutas } & \text { Universal de fract. } 2.4 & \mathrm{Si} / \text { ?? } \\ & \text { Unilock } 2.4 & \mathrm{Si} \\ \text { IO microvascular } & \text { Miniplacas } 2.0 & \\ & \text { Universal de fract. } 2.4 & \mathrm{No} \\ \text { Unilock } 2.4 & \\ \text { Osteosíntesis Puente } & \text { Unilock } 2.4 & \\ & \text { Reconstrucción } 2.7 & \text { Thorp } 4.0 \\ \end{array}$

Table 2. Comparison of the 2.0 Unilock plates and conventional systems according

Indications

Simple orthognathic ractures

Multiple and complex

Comminuted fractures

$$
2.4 \text { Unilock }
$$

2.0 Miniplates

2.4 Universal fract. 2.4 Unilock

2.4 Unilock

2.7 reconstruction 4.0 Thorp

intraoperatively. As we have already mentioned, it represents a considerable relief regarding threedimensional molding of long implants, but it is also very interesting in relation to the application of small implants for osteosynthesis in areas with difficult access such as the mandibular condyle. The experience collected in this pilot study initially defines the indications and limitations of this system (Table 2). Even if the indications appear to be well-established (load sharing osteosynthesis), the same cannot be said of the contraindications; indeed, it is been well-known that the resistance of these plates is not

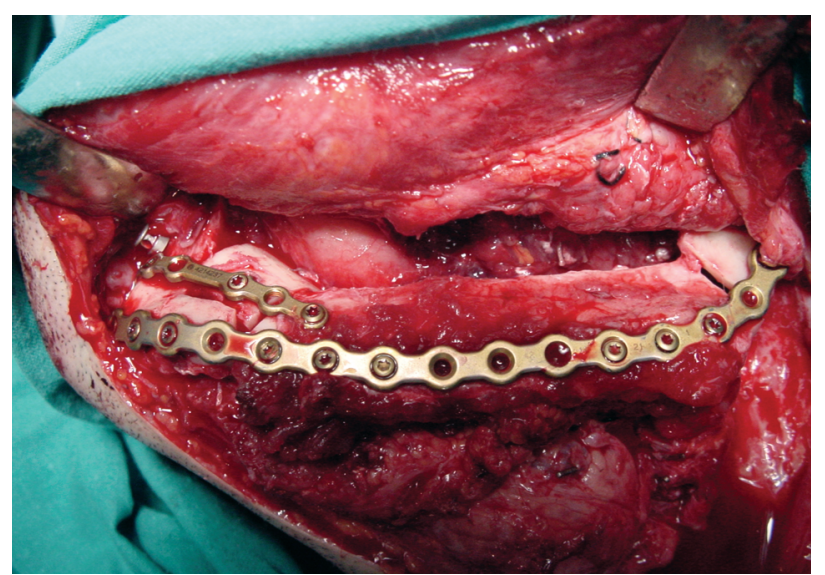

Figura 9. Fijación de peroné microvascularizado con placa large y una medium a nivel sinfisario para reconstrucción mandibular tras resección de un sarcoma ameloblástico.

Figure 9. Microvascularized fibula fixation with large and medium plate in the symphyseal region for mandibular reconstruction following resection of ameloblastic sarcoma. adequate for supporting load bearing osteosynthesis conditions (the only exception would be the fixation of microvascularized bone grafts) such as bridging osteosynthesis or the fixation of an NVBG. (Fig. 9) In comminuted fractures cases, the implant of choice would be the 2.4 system. In our series there are two cases in which the election of the 2.0 system was not a whim; in the patient that was nearly edentulous due to a bullet, the condition of his soft tissues led us to take this decision in an effort to 
una experiencia suficiente para definirse respecto a los casos de mandíbula atrófica (donde el perfil de las 2.0 sería muy deseable respecto a las 2.4 al tratarse de pacientes añosos con piel laxa y escasa musculatura) o de osteomielitis focal establecida. En cualquier caso deberemos individualizar nuestra decisión en cada situación concreta basándonos en el conocimiento de las ventajas e inconvenientes de cada sistema, con el que debemos estar familiarizados de forma adecuada. Como norma general aconsejamos en los casos "limítrofes" el empleo del sistema 2.4, que si bien es más engorroso de manipular, ofrece prestaciones ya contrastadas.

\section{Conclusiones}

Los implantes del sistema Unilock 2.0 cubren el hueco existente entre las miniplacas y las placas rígidas incorporando los beneficios de los sistemas de bloqueo, posibilitando hasta el $90 \%$ de las osteosíntesis mandibulares. Son placas más estrechas y de bajo perfil que permiten evitar en muchas ocasiones la introducción de una placa rígida grande, con menor irritación de los tejidos blandos y una mejor vascularización ósea. La presentación del hardware en un pequeño set y sus refinados diseños permiten una manipulación muy sencilla con lo que se agilizan los tiempos quirúrgicos y se minimizan los errores de instrumentación. Será necesario un estudio prospectivo y comparativo para definir con exactitud las indicaciones, limitaciones y beneficios de este sistema con respecto a los convencionales: miniplacas y placas de reconstrucción.

\section{Bibliografía}

1. Sutter F, Raveh J. Titanium-coated hollow screw and reconstruction plate system for bridging of lower jaw defects: Biomechanical aspects. Int J Oral Maxillofac Surg 1988;17:267.

2. Herford A, Ellis E. Use of a locking reconstruction bone plate/screw system for mandibular surgery. J Oral Maxillofac Surg 1988;56: 1261.

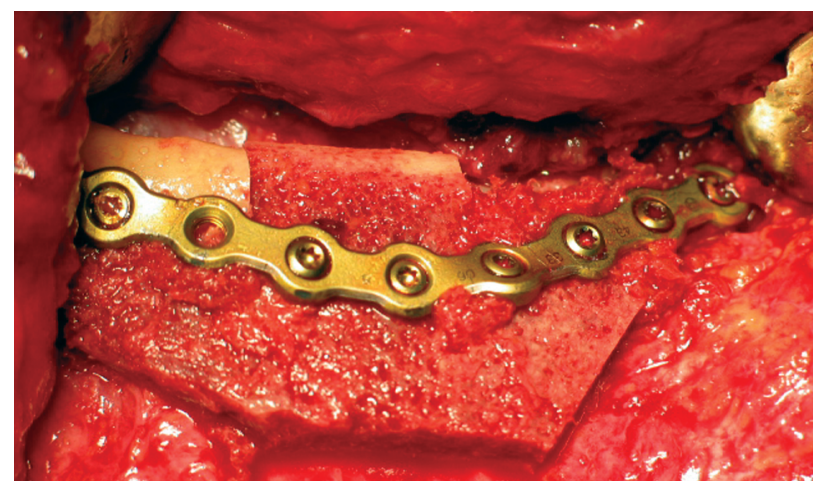

Figura 10. Imagen intraoperatoria y control radiológico de IONV para reconstrucción de defecto mandibular por fracaso de osteosíntesis semirígida en una osteotomía de abordaje.

Figure 10. Intraoperative image and radiologic control with NVBC for reconstruction of the mandibular defect because of failure with semi-rigid osteosynthesis in an approach osteotomy.

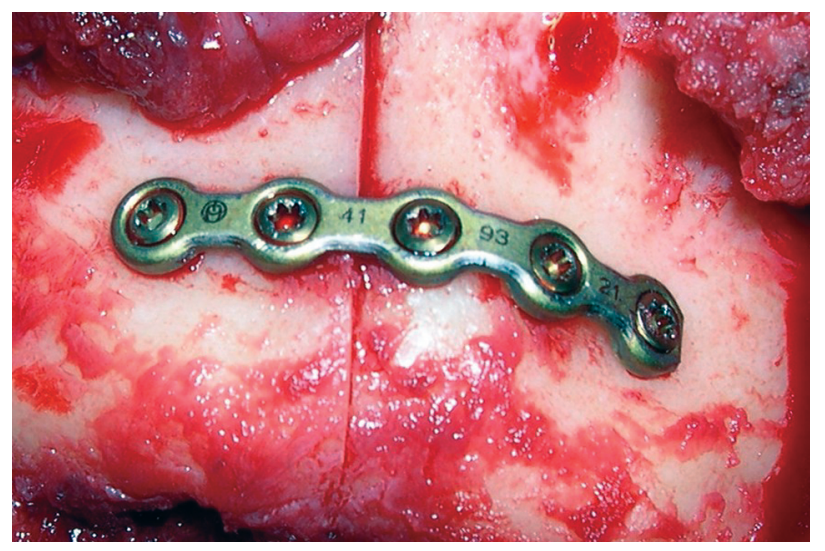

Figura 11. Fijación de abordaje de Trotter. Fijación de mandibulotomía lateral y refuerzo de mandibulectomía segmentaria oncológica.

Figure 11. Fixation of Trotter approach. Fixation of the lateral mandibulotomy and reinforcement of the oncologic segmental mandi bulectomy.

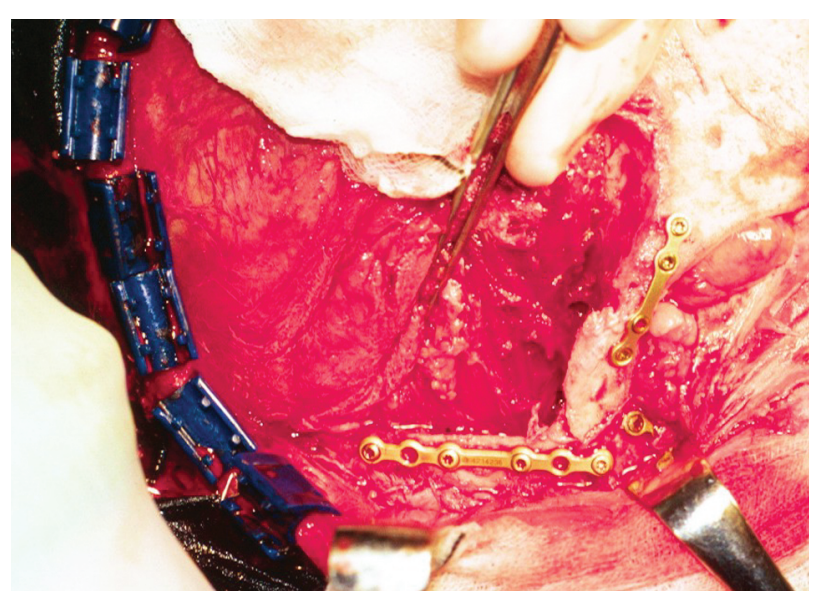

Figura 12. Fijación de fractura compleja orbito-cigomática con placas mini en el contexto de una fractura panfacial.

Figure 12. Complex orbital-zygomatic fracture with mini plates in the context of a panfacial fracture. minimize the possibility of exposure, given the reduced profile of the plates. In the second case, the presence of a condyle fracture and the resulting need for postoperative intermaxillary fixation encouraged us to use the 2.0 system with good results. In both cases the complications can be considered to be independent of the system used, appearing later following complete consolidation and normocclusion.

With regard to the NVBC case, this was a young irradiated patient with a small face and fine skin, with reduced biomechanical requirements (mastication/collaboration). The result was very satisfactory even though she in fact underwent "preventative" intermaxillary fixation for three months that may not have been needed had we used a 2.4 system. (Fig. 10). In cases of approaches involving osteotomies, they are a reliable alternative that can on occasion reinforce marginal mandibulectomies (Fig. 11) although with radiotherapy the 2.4 system should first be considered. Finally, even though this system has been designed specifically for mandibular osteosynthesis, it can be particularly useful for cases involving panfacial fractures as with the same set, with identical drills and screws, we can perform osteosynthesis of the mid-face and orbit (with mini plates) making instrumentation much simpler (Fig. 12).

Conclusions cannot evidently be made of these isolated cases, but the aim is to show that the limits are not clearly defined. For example, there 
3. Söderholm A, Lindqvist C, Skutnabb K. Bridging of mandibular defects with two different reconstruction systems: An experimental study. J Oral Maxillofac Surg 1991;49:1098.

4. Lindqvist $C$, Söderholm A, Laine P. Rigid reconstruction plates for immediate reconstruction following mandibular resection for malignant tumors. J Oral Maxillofac Surg 1992;50:1158.

5. Raveh J. Lower jaw reconstruction with the THORP system for bridging of lower jaw defects. Head Neck Cancer 1990;2:344.

6. Stoll P, Wächter R, Bähr W. Bridging lower jaw defects with AO plates: Comparison of THORP and 3-DBRP systems. J Craniomaxillofac Surg 1992;20:87.

7. Klotch D, Gal T, Gal R. Assessment of plate use for mandibular reconstruction: Has changing technology made a difference? Otolaryngol Head Neck Surg 1999;121:388.

8. Gutwald R, Büscher P, Schramm A. Biomechanical stability of an internal minifixation system in maxillofacial osteosynthesis. Med Biol Eng Comp 1999;37:280.

9. Lindqvist C, Söderholm A, Salo A. A comparative study on four screw-plate locking systems in sheep: A clinical and radiological study. Int J Oral Maxillofac Surg 2001;30:160.

10. Haug R, Street C, Goltz M. Does plate adaptation affect stability? A biomechanical comparison of locking and nonlocking plates. J Oral Maxillofac Surg 2002;60:1319.

11. Kirkpatrik D, Gandhi R, Van Sickels J. Infections associated with locking reconstruction plates: A retrospective review. J Oral Maxillofac Surg 2003;61:462.

12. Ellis E, Graham J. Use of a 2.0-mm locking plate/screw system for mandibular fracture surgery. J Oral Maxillofac Surg 2002;60:642.

13. Gutwald R, Alpert B, Schmelzeisen R. Principle and stability of locking plates. Keio / Med 2003;52:21.

14. Alpert B, Gutwald R, Schmelzeisen R. New innovations in craniomaxillofacial fixation: the 2.0 lock system. Keio / Med 2003;52:120. is not enough experience that allows evaluating cases of atrophic mandibles (where the 2.0 profile would be highly preferable to the 2.4 profile for elderly patients with lax skin and little musculature) or of established focal osteomyelitis. In any event, we should individualize our decisions according to each concrete situation, and these should be based on our knowledge of the advantages and disadvantages of each system that we should be adequately familiar with. As a general rule we advise that for "borderline" cases the 2.4 system should be used as, although it is more cumbersome to use, its performance has been contrasted.

\section{Conclusions}

The 2.0 Unilock implant system covers the existing gap between the miniplate and the rigid plate. It incorporates the advantages of the locking system allowing mandibular osteosynthesis to be carried out $90 \%$ of the time. These are thinner plates with a lower profile meaning that, on many occasions, the introduction of a larger rigid plate is avoided. Soft tissues are less irritated and vascular supply to the bone is greater. The presentation of the hardware in a small set and its refined design, allow simple manipulation. Surgical times are therefore speeded up, and instrument errors are minimized. A prospective and comparative study will be required in order to define precisely the indications, limitations and benefits of this system with regard to conventional systems: miniplates and reconstruction plates. 